\title{
Jack Ruby's complex: the factors driving the assassin of lee Harvey Oswald
}

\begin{abstract}
Jack Ruby, the assassin of Lee Harvey Oswald, has been consigned to a footnote of history. What Ruby did was to eliminate the only man who could explain the assassination of the US President, setting in train a mass conspiracy delusion that continues to cast doubt on the likely assassin to this day. Who was Jack Ruby, and what motivated him to do this murder that changed history? Ruby's fragmenting Jewish identity played a significant role in the events that led to the killing of Oswald and the loss of his sanity. In the year prior to the Kennedy visit, his mental state was changing. In a paranoid state, Ruby's behaviour was driven by a belief that there was an anti-Jewish conspiracy behind the killing of the President. In addition, his use of dietary amphetamines increased. Ruby's trial, followed by his time in prison until his death several years later, was characterised by increasingly irrational utterances that were filtered through his Jewish identity. A review of the evidence shows that organic factors affected his mental state. Ruby's killing of Oswald reflected aspects of the American Jewish migrant experience, his dysfunctional personality, abuse of amphetamines and the probably effect of a silent brain tumour. Like the first real cowboy spotted by a child, Ruby made an indelible impression upon my youthful consciousness. He was the first Texas Jewboy I ever saw. There he stood, like a good cowboy, like a good Jew, wearing his hat indoors, shooting the bad guy who'd killed the president and doing it right there on live TV. ..., Ruby had done what every good God-fearing red-blooded American had wished he could do. And he was one of our boys! Kinky Friedman ${ }^{1}$ he was a good ole boy that Jack Ruby all right. Michael Englebert. ${ }^{2}$
\end{abstract}

Volume I Issue 6 - 2015

\author{
Robert M Kaplan \\ Forensic Psychiatrist, University of Wollongong, Australia \\ Correspondence: Robert M Kaplan, Forensic Psychiatrist, \\ Clinical Associate Professor, Graduate School of Medicine, \\ University of Wollongong, PO Box 316, Thirroul, NSW 25I5, \\ Australia, Tel 6 I 24268 3949, Email rob@rmkaplan.com.au
}

Received: October 18,2015 | Published: December 10, 2015

\section{Introduction}

The world's most public execution, watched by millions of television viewers, occurred at 11.21 a.m. on 24 November 1963 before the assembled media at the Dallas police station. Lee Harvey Oswald, the assassin of President John F. Kennedy, following interrogation at Dallas police headquarters, was to be transferred to prison. To get to the van, he had to pass through a crowd of police, journalists and television cameras. Just before he was to leave, Oswald (all his life a chronic obfuscator) delayed several minutes to change his shirt. As he came out of the door before the press, the cameras whirled, a burly man standing in the crowd stepped forward and fired a Colt pistol into Oswald's lower belly, gruffly shouting, 'Oswald!' Looking surprisedthe last expression in his life-Oswald crumpled to the ground, virtually lifeless. He died two hours later. The public murder was seen live by an estimated eighty million viewers around the world. The man who fired the gun at Oswald made no effort to escape. He appeared pleased with himself, expecting to be congratulated for what he did, saying to the police: 'I'm Jack Ruby, you all know who I am.' Jack Ruby, for the most understandable of reasons, does not feature much, if at all, in the literature on twentieth-century Jewish history in the United States.

In any literature of the period, Ruby, at most, rates as a footnote; the man who in a moment of insanity, was to eliminate the only man who could explain the assassination of the US President, setting in train a mass conspiracy delusion that continues to cast doubt on the likely assassin to this day. While Ruby bore some remarkable similarities in the path he followed to his victim Oswaldm, ${ }^{3}$ in the megalith of literature that has sprung up from the assassination, any mention of Ruby invariably arises from the conspiracy theories that attempt to link him with the criminal underworld, organised crime, government intelligence agencies or Oswald himself - all without any substance whatsoever. ${ }^{4}$ Leaving out the more histrionic notions, the documentation on Ruby portrays a slightly unstable, highly impulsive wannabe who, through a fortuitous chain of events, was in a position to shoot Oswald for the most spurious of reasons: to spare Jacquelyn Kennedy the ordeal of testifying at his trial.

One thing everyone was aware of: Ruby was Jewish, leading a near-demimonde existence in Dallas, a town where Jews, despite several high-profile identities, mostly stayed below the radar. Any scrutiny of Ruby's background and path through life will show that he followed a similar trajectory to many other Jews whose parents had come to the US from Eastern Europe. Ruby's fragmenting concept of his Jewish identity played a significant role in the events that led to the killing of Oswald and the loss of his sanity. Ruby's trial, followed by his time in prison until his death several years later, was characterised by increasingly irrational utterances that were filtered through his Jewish identity. A review of the evidence shows the organic factors that effected his mental state.

\section{Ruby's history before the assassination}

Ruby's father Joseph Rubenstein came from Sokolov, a Polish shtetlnear Warsaw, then in the old Pale of Settlement of the Russian Empire. ${ }^{5} \mathrm{He}$ was conscripted into the Tsarist Army in 1893, a fate that amounted to a life sentence unless one could escape. In the army, Rubenstein learned carpentry (which had been practiced by his father and brother), before marrying Ruby's mother Fannie Turek Rutkowski, probably born in 1875 , who came from a marginally more up-market Jewish family near Warsaw. Later, in prison, Ruby was to write a fanciful account of Joseph having stayed with and married a Jewish farmer's daughter when, in fact, the marriage was arranged by a professional matchmaker. ${ }^{6}$ Serving in China, Korea, and Siberia only added to his disaffection with military life, before going AWOL in 1898 and via, England and Canada, entering the United States in 1903, settling in Chicago. For Joseph Rubenstein, the legacy of his 
military life was learning to drink, a habit he maintained for the rest of his life, and how to use his fists, which was to become the habitual reaction of his son Jack. Fannie Rubenstein, accompanied by her children Hyman and Ann, followed her husband to the United States in 1904 or 1905.

The couple, who were quite unsuited, proceeded to have at least eight children-at least one if two other children died during infancy Jack Ruby, born Jacob Rubenstein, on 19 March 1911, was the fifth child; two younger brothers and a younger sister followed him. At the time Ruby was born, the family was living near 14th and Newberry Streets in the Maxwell Street ghetto district ${ }^{7}$ according to Ruby, they were half a block away from Maxwell Street. ${ }^{8}$ From 1916 until 1921 , the Rubensteins lived at 1232 Morgan Street, the fourth residence in Jack Ruby's first 5 years. Ruby Senior drank, was violent, seldom held a job and deserted the family for most of Jack's teenage years. He joined the carpenters union in 1904 and mixed with fellow migrants from Sokolov, indicating his attachment to his landmanschaft. He worked at intervals until 1928, but was unemployed during the last 30 years of his life. Fannie Rubenstein, described as severely neurotic, was quite unsuited to the task and would have struggled to hold together a large family, under any circumstances. Although she learned some English, her speech was predominantly Yiddish, the primary language of the Rubenstein household.

An illiterate woman, she went to night school in about 1920 to learn how to sign her name. To her credit, this led her to insist that her children required an education. She frequently argued about this with her husband, who had received little education and believed that grammar school training was sufficient for his children. Fannie Rubenstein had no ability to control her children. Her mental state gave in, she was hospitalised, Following the intervention of the Jewish Social Service Bureau, some of the Rubenstein children, including Jack, had to spend time in foster homes. Jack, Sam, Earl, and Eileen Rubenstein were wards of the Jewish Home Finding Society for short periods in 1922-23. It appears they spent some time in private foster homes, as well as a farm; Ruby spent eighteen months in foster homes. Rubenstein Senior remained apart from the children at least until 1936 and perhaps a few years later when the parents were apparently reconciled. Mrs Rubenstein later died in a home on 11 April 1944, having become paranoid, which was attributed to early senility. Her children remembered her with affection, perhaps because she favoured their education and they recognized her difficulties in rearing them during a turbulent marriage. Jack was especially fond of his mother. After his wife's death, Joseph Rubenstein stayed with the children, where he died on 24 December 1958.

Life for poor Yiddish-speaking migrants on arrival in the United States was hardly a picnic, and the rough side of Chicago was about as bad as it got. Earl Ruby described the neighbourhoods in which the family lived as ghettos with "pushcarts on the sirens." His sister Eva characterized them as "below the middle class but yet it wasn't the poorest class." These circumstances fostered truancy and Ruby was assessed by a psychiatrist when he was eleven. Ruby had learning problems and would misspell and mispronounce words all his life. His IQ was ninety-four-within normal levels, but he was hardly likely to progress beyond high school. He left school after fifteen, continuing his education on the streets. For the Rubenstein children, growing up in a mostly single parent family in the rough side of Chicago, their Jewish identity was taken as a given. The family often lived near Italian neighbourhoods, where there were frequent fights along ethnic lines. ${ }^{10}$ In the "tough" neighbourhood where they lived, self- defence was vitally important. ${ }^{11}$ Whether they wanted it or not, they were identified as Jews, measured off against the ethnic groups that surrounded them. The result of such identification, however unsought, was to reify the issue; they had to stay together for protection, if nothing else. Like his siblings, Ruby would have been picked on and bullied for this reason. He seems to have been different to some extent by his willingness to fight back physically, assisted by his burly build and fistic ability. The reason he followed this course arose from his intelligence and personality. His quick temper, no doubt modelled on his father and many others he encountered during his upbringing, was a product of his sense of inferiority. Where many Jewish boys in the same situation would have tried to talk their way out by wit, humour and sheer chutzpah, all Ruby could do was bluster and then lash out. This may have earned him the respect of his persecutors, it did little for his self esteem and left him with the uneasy feeling that his intellectual resources were more limited than those around him. ${ }^{12}$

Exerting himself by his physical presence and aggression was the only way Ruby knew to prevent a constant sense of inferiority from surfacing in any encounter. Like many Jews, he modelled himself on the boxing champions of his day and used violence to fill the gap. ${ }^{13}$ To this can be added his preoccupation with appearance, manifesting in exercising, weight-lifting and dieting. ${ }^{14}$ While Ruby had no religious education outside the public school system, his parents made an effort to inculcate the children with the Orthodox Judaism tenets. Jewish dietary and festival laws were observed and Joseph Rubenstein would take several of the children to the synagogue. Earl Ruby stated that all the boys received some Hebrew school training until the breakup of the Rubenstein home in 1921. The information available leaves no doubt that from an early age Jack Ruby was aware of his Jewish identity, although his involvement in orthodox ritual practices was limited. Like many second-generation Jews in America, Ruby made his Jewish identity a central feature of his persona and always associated with Jewish people although his religious practice was limited. Virginia Belasco, granddaughter of the playwright and actor David Belasco, met Ruby in about 1936 at a dance at the Jewish community centre in San Francisco and at several other social occasions between 1936 and $1941 .{ }^{15}$

Ruby's ascent, nevertheless, was fitful, if not erratic. He always had difficulty earning a living. He lived by his wits, a hustler selling anything that could earn a quick buck, from scalping tickets to hocking cigarettes and peanuts, peddling horse-race tip sheets, ${ }^{16}$ vending pennants at sports events, selling door to door newspaper subscriptions, real estate, gimmicks and gadgets. ${ }^{17}$ This was a common trajectory for someone in Ruby's position; as a rule, people either moved up or down the social scale as they got to adulthood. ${ }^{18}$ If they moved down, minor brushes with the law would escalate into more serious crimes and violence, setting them up to be a career felon and criminal, often based in an ethnic gang. ${ }^{19}$ Alternately, they could follow an upward path-socially, occupationally, economically and legally - into the American melting pot; the vast majority of secondgeneration Jews did this. Ruby and his siblings followed the latter path, although with some fits and starts. He had few legal problems, mostly minor transgressions. When he was fifteen, while trying to sneak into a ballgame, Ruby was hit on the head by a policeman. His family later said he was hospitalised with a serious head injury, having a steel plate inserted into his skull, but this seems unlikely.

Despite the disruptions and difficulties, the children remained close, maintained their Jewish identity-albeit in a less devout form to cope with a different lifestyle to that of Eastern Europe-and then 
got on with their lives. Ruby, after going to some effort to avoid the authorities (including wearing a hearing aid to pretend he was deaf) was inducted into the U.S. Army Air Forces on 21 May1943. ${ }^{20}$ Ruby spent his military days as a private at several airbases in the South. He was described as a Sergeant Bilko character, always looking for ways to hustle the system. It was reported that he was extremely sensitive to insulting comments about Jews. When a sergeant called him a "Jew bastard" during an argument, Ruby attacked him with his fists, but did not incur any penalty later. He was honourably discharged on 21 February 1946. Ruby came out the Army with both an enhanced sense of patriotism and pride. He was described as ready to fight with any person who insulted Jews or the military. His brother Earl testified that on one occasion in 1946, Ruby returned from downtown Chicago with his suit covered with blood. He explained at that time that he had fought with a person who had called him a "dirty Jew or something like that." He was reported to go to meetings of the German Bund where he "cracked a few heads". Following his return to civilian life, Ruby mostly worked as a travelling salesman, spending time in San Francisco. He was involved in setting up the Waste Material Handlers Federal Union. Leon Cooke, the union president, was shot but this did not involve him. Mostly, Ruby was going nowhere.

\section{The Dallas years}

On 30 December 1947, Ruby moved to Dallas, Texas, where his sister Eve was already established and assisted him to get established in the first regular occupation he had-nightclub owner. Later his brother Sam, to whom he was not as close, moved there. As an indication of his intention to adapt to the new location, he then legally changed his name to Jack Leon Ruby. ${ }^{21}$ His petition to the 68th Judicial District Court of Dallas alleged that he sought the change because the name Rubenstein was misunderstood and too long and because he was "well known" as Jack L. Ruby. Americanising a surname was not uncommon for Jews trying to assimilate in US society. Earlier that year, his brothers Earl and Sam had changed their names to Ruby. Earl later testified that he changed his name because everyone called him Ruby and because a former employer advised him that it was preferable not to use a "Jewish name" on mail orders for his business. Ruby may have taken this step to make himself stand out less in Dallas, a town hardly receptive to a Jewish hustler from the wrong side of Chicago. ${ }^{22} \mathrm{He}$ dealt with this by adopting the local ethos, wearing large-brimmed hats, high collars and going to clubs dressed in Western outfit, leading to him being known as the Chicago cowboy. Before long, Ruby went into the nightclub business. But after five years, his situation was looking dire.

The failure of his club in 1952 led to him being briefly on the streets, having to return to Chicago for several months in a state of depression. He bounced back and returned to Dallas. He managed to get back in the business and followed along this path, just managing to keep his head above water, until 1963. By then, he ran a rock-androll dance hall, The Vegas Club, and a strip club, The Carousel Club. The Vegas was run by his sister and the Carousel became the central focus of his activities, if not his identity. Ruby liked to portray it as a classy entertainment joint, but in reality, it was a strip club catering to tourists, visitors and anyone who had a taste for seedy burlesque. He was his own bouncer and would use his fists more than was necessary. This tough-guy image was reinforced by working out in the gym. Ruby would press invitation cards into the hands of anyone he met. He liked to describe himself as a ganzer macher-a big man around town. A police groupie, Ruby encouraged officers to come to the club where they were always treated generously, often walking out with a bottle of whisky under their arm. There was, of course, an element of self-interest in this as it was easy to lose his liquor licence if the police issued an adverse report. He also was a minor snitch which had mutual benefits; it provided information to the police on offenders and fed Ruby's need to feel that he was a law enforcement player.

While Ruby liked to big-note himself as a high-ranking mobster running a hotshot nightclub, an associate of leading figures in the Dallas demimonde, and an intimate of police, press and politicians, all serious writers regard the idea of Ruby having connections to organised crime as risible. The truth is that far from being a mob lieutenant, Ruby ran two seedy clubs that barely managed to survive was dependent on not antagonising the real mobsters to ensure that his clubs stayed open. ${ }^{22}$ An inveterate self-promoter, he constantly inflicted himself on anyone he met, pressing invitation cards in their hands. ${ }^{23} \mathrm{He}$ was friendly with the police-who tolerated him as a minor snitch who gave them freebies at the club, and hung around the press-who regarded him as a 'born loser'. Ensconced in Dallas, Ruby joined the local Conservative Synagogue, Shearith Israel in Dallas where Rabbi Hillel Silverman conducted services. ${ }^{24}$ Ruby was only devout in the most limited way. He did not read Hebrew and only attended services on the Jewish high holidays. He paid the synagogue fees to reserve seats for the high holidays. Silverman reported that when Ruby's father died in 1958, Ruby came to services twice daily for the prescribed period of 11 months to recite the Kaddish. He had something of a pastoral relationship with Rabbi Silverman, visiting him on several occasions to discuss his problems..$^{24}$ Ruby went to the Friday night service immediately after the Kennedy assassination, where his distress was evident to all.

\section{The assassination}

By the time of the presidential visit, Ruby's accomplishments had been below the waterline for years. No amount of bluster could hide the fact that he was a nonentity, constantly seeking recognition but regarded with contempt or disdain by those who counted in Dallas. He ran the Carousel Club at night, usually getting home at $3 \mathrm{am}$. His strippers both loved and loathed him. He worked his way through them sexually and could threaten violence when they upset him, but would go to extraordinary lengths to help them if they had trouble, especially with boyfriends. He still looked after unruly patrons, seeming to relish the opportunity to become physical, often using knuckledusters for emphasis. He had George Senator, a Korean War veteran, living at his apartment for a year [25]-which was later thought to indicate that he was homosexual, although this was strenuously denied.

Ruby's mental state had been deteriorating in the year before the assassination. The Warren Commission noted, "Ruby was regarded by most persons who knew him as moody and unstable-hardly one to have encouraged the confidence of persons involved in a sensitive conspiracy". ${ }^{26}$

Rabbi Silverman recalled that in 1962, the year before the assassination, Ruby suddenly appeared on his front yard with half a dozen dogs. He began to cry, saying, 'I'm unmarried'; pointing to one dog, he said, 'This is my wife,' and, pointing to all the dogs, he said, These are my children.' Silverman considered Ruby "a very emotional, unstable, erratic man". ${ }^{27}$ This was the Jack Ruby who waited in anticipation of the arrival of his hero, President John Kennedy in Dallas-yet such was his distracted mental state by then that he never even went to the parade. In truth, it was not Oswald's 
presidential slaying but in the most anodyne way when he opened his newspaper that morning that the faulty construction that was Jack Ruby began to implode. The first sign of anything amiss with Ruby's perceptions on that fatal day in Dallas occurred on the morning before the presidential group had arrived. Reading the Dallas Morning News, Ruby's attention was caught by a half-page advertisement, bordered in black, accusing the President of being a communist tool, signed by 'The American Fact-Finding Committee, Bernard Weiss man, Chairman'. The advertisement incensed Ruby, who thought it was disrespectful of the president, more so because it was signed by someone who appeared to be Jewish. Ruby believed that the advertisement was a right-wing conspiracy aimed at discrediting Jews. As it happened, Bernard Weissman, the man who had placed the ad was a 26-year old salesman with links to Dallas conservatives, was not Jewish ${ }^{28}$ and there is nothing to indicate that it was an anti-Jewish conspiracy, let alone a plot.

The possibility of an anti-Jewish conspiracy weighed on Ruby's mind throughout the day. When he heard that Kennedy had been assassinated, he was devastated, breaking down in tears. So intense was Ruby's distress that, despite the trauma of the event, it surprised many who knew him. He could not understand how anyone would want to murder his hero, a man who held the highest office in the land. His sister was to later say that he took the death of the President even harder than that of his father in $1958 .{ }^{8}$ His anguish notwithstanding, the political advertisement did not leave Ruby's thinking. He spoke to a journalist on the paper and went round to the Times Herald office at 4am, complaining that the advertisement in The Dallas Morning News was a conspiracy to make the Jews look bad. His preoccupation with the matter worsened when he saw a roadside billboard with the inscription, in large letters, 'Impeach Earl Warren', which listed the post-office box number (1754). In his inflamed state, with his inbuilt reading difficulties, Ruby immediately linked the number with that listed with the newspaper advertisement (1972).

At $5 \mathrm{am}$ he went to the billboard with George Senator and one of his staff to take Polaroid photos of the poster, then driving down to the post office to look at the box, annoyed to see that it contained a large volume of mail. Shortly after, when he opened the morning paper to see the Weissman advertisement again, he unleashed a long tirade to George Senator on the matter. Senator later commented that he kept rereading the advertisement with tears in his eyes and 'a strange and abnormal stare'. This was all highly unusual behaviour. Distraught at the President's death, Ruby had contacted his rabbi and his sister, almost making a public spectacle of his grief in a city (if not the whole country) that was paralysed by the news. Yet, from the morning before the arrival of the cavalcade through the news of the shooting until well into the next morning, Ruby's activities, random or otherwise, were driven by one overriding obsession: the presumed plot by right-wingers to implicate the Jews of America. It was in this frame of mind that he faced the rest of the fateful day. Until 11.18am, Ruby's activities were mostly routine, attending to matters at his club, paperwork and then going to the Western Union office to send money to one of his strippers, leaving his beloved dog Sheba in the car. ${ }^{29}$

The evidence has been repeatedly and convincingly reviewed. If Ruby had any serious plan to kill Oswald (for his own reasons or for someone else), as the conspiracy theorists still allege, then this would have been the worst possible way to go about it. Had it not been for a single last-minute and totally unpredicted decision to delay Oswald's departure, he would have missed him completely. Then, he walked across the road to the police centre where he glided easily into the crowd of police and press awaiting the passage of Oswald to the police truck. Three minutes after leaving the Western Union office, he had shot Oswald and been arrested. No one can put themselves in Ruby's mind at the instant that he saw Oswald in the police parade and lunged forward with his gun. His presence at the Dallas police headquarters was, in all likelihood, driven as much by his habitual desire to be at the centre of everything as anything else. As much as one can untangle the flitting and surging emotions that Ruby was operating under at the time, at the centre of the emotional cyclone was a conspiracy that threatened to swamp him and everything he valued. That he carried a gun on him in Dallas, Texas, was nothing unusual. He later said it was something in Oswald's smirk that triggered him, but admitted that he was in a daze and could not recollect what happened. In the heated emotion of the situation, everyone present had reason to have strong feelings about Oswald and his habitual demeanour, smirking or otherwise, only facilitated this. But it was only Ruby who shot him.

In the first flush of the slaying, Ruby experienced a surge of hubris such as he had never known. Ruby told reporters that he had been reading the Bible and "the truth has come to me during incarceration". "I am not frightened ... I am a 100\% American who loves his country. I love my President. I have intestinal fortitude. I want to do so much for democracy". ${ }^{30}$ Trial, Jail and death following his jailing, Ruby's emotions swung wildly. The initial elation that he would be regarded as a hero and immediately released-an idea that even under the circumstances must be regarded as near-delusionalsoon crumpled in the face of the response of most people who were appalled at what he had done. ${ }^{31}$ As the implications of his act sunk in, he slumped further and further into a mire from which he never emerged. The trial that followed was even worse. ${ }^{32}$ The prosecution calmly laid out its case, showing that Ruby had been obsessed by the presidential assassination, telling people that Oswald should be shot to spare Kennedy's widow any more grief. He had to sit silently through it all, listening to himself described as a mentally unstable individual who needed to be institutionalised, a latent homosexual and, worst of all, a loser. ${ }^{32}$ That his attorney, Marvin Belli, was prone to referring to him as a "poor little Jew boy" did not help the situation. ${ }^{31} \mathrm{He}$ did not give evidence-a serious error in the light of his deteriorating mental state as the trial progressed. If he was not insane by the start of the trial, he certainly was by the time it finished. ${ }^{32}$

After a brief discussion, the jury found Ruby guilty and he was sentenced to death. The paradox is that while the jury rejected the insanity defence, he was already psychotic. Awaiting his appeal in jail, Ruby's mental state continued to deteriorate. Rabbi Silverman visited him regularly, aware that he was the first-ever Jew sentenced to be executed in Texas. ${ }^{24}$ It was evident to all that he was grossly delusional. He believed his brother had been tortured, castrated and burned to death in the street outside his cell, and the Jews in America were being killed in a pogrom because the Kennedy assassination was blamed on him. Interviewed by neuropsychiatrist Dr. Louis Jolyon West, he said that he was convinced that all the Jews in America were being slaughtered in retaliation against him "the Jew responsible for all the trouble". ${ }^{33} \mathrm{He}$ became suicidal, on one occasion ramming his head against a wall, another time trying to electrocute himself. Ruby's delusions about the conspiracies he saw around him continued to escalate. He would slip his visitors bits of paper with phone numbers scribbled on them in an oddly womanish hand, whispering desperately: "These people have been murdered. They're all out to get the Jews, and these people (his sister Eva and his brother Earl) 
won't answer the phone because they're dead." When he became ill, Ruby screamed that his jailers were piping mustard gas into his cell. ${ }^{34}$

He made persistent appeals to the Warren Commission investigating the assassination to give testimony, requesting to be interviewed in Washington as he claimed his prison was unsafe. This was refused and he was interviewed in jail by members of the Commission, who were unimpressed with his paranoid rodomontade. His testimony gives an account of his mental state and preoccupation with conspiracies against Jews: "The Jewish people are being exterminated at this moment. Consequently, a whole new form of government is going to take over our country, and I know I won't live to see you another time. Do I sound sort of screwy in telling you these things?". ${ }^{35}$ Ruby's appeal succeeded and he was granted a retrial on the grounds of unfair pre-trial publicity. However, he never faced his accusers again. ${ }^{36} \mathrm{By}$ then his physical condition was deteriorating. He had constant stomach pain. Ruby collapsed; in hospital he was found to have lung cancer with brain secondaries and soon died. ${ }^{37}$ The official cause of death was listed as pulmonary emboli (blood clots) in the lungs from his legs. Ruby was buried alongside his parents at Westlawn Jewish Cemetery in Chicago. ${ }^{38}$ The service was conducted according to Jewish conservative ritual by Rabbi David Graubert, who described him as a misguided patriot and avenger.

\section{Discussion}

All his life, Ruby was impulsive, in part because of his learning difficulty which caused subtle comprehension problems, in part because of a pervasive sense of failure which he compensated for with a range of behaviours intended to demonstrate his manliness, authority and refusal to be cowed. By the time of the President's visit, Ruby's often shaky control of his emotions was affected by two factors of which neither he nor anyone else was aware: a silent brain tumour, possibly in his frontal lobes; and the effects of the amphetamines which he was taking to excess. The changes went way beyond his usual edgy sense of being at odds with a hostile world in which he had to continually flaunt himself to gain even token recognition. In all likelihood, his loss of control and ability to distinguish reality from fantasy had started slowly but the heightened emotional tension of first the President's impending visit, then the assassination, imploded his hold on reality. Always concerned about his weight and appearance, Ruby would work out at the gymnasium and use diet drugs, notably Benzedrine and Preludin; in short, he was on a cocktail of highly stimulant amphetamine drugs, ${ }^{39}$ a combination notoriously conducive to aggression, paranoia and violence.

Bugliosi and Posner, the two most credible writers on the assassination, state that Ruby was dieting at the time-the implication being that he would be taking more of the drugs than usual, or had just started taking them again. ${ }^{40}$ Judge Brown, who tried Ruby and wrote a somewhat self-serving account of the trial, ${ }^{41}$ was to state that Ruby had taken 30 tablets on the morning he shot Oswald-highly unlikely, but suggesting high doses nevertheless. The result would be the same. While he would lose appetite, Ruby also ran a greater risk of side effects including impulsivity, aggression, violence, paranoia and grandiosity. The last factor should not be underestimated. For Ruby, a serial loser with just enough intelligence to know that everyone else knew it as well, this would have been almost as lethal as the paranoia. The likelihood that Ruby's behaviour was affected by high doses of amphetamines is reinforced by Posner's statement that once he was imprisoned, deprived of these medications, he went through withdrawals and his mood plummeted. When Ruby's car, which also functioned as an alternative office, was searched, amid the mess was found pictures of the billboard and his diet drug prescriptions. It will remain speculative whether Ruby had a silent (asymptomatic) brain tumour when he shot Oswald, but the natural history of cancer, especially bowel cancer, is consistent with this possibility.

Without Ruby or anyone around him realising, the silent tumour altered the balance between the reality of his perceptions of the world around him and a profound feeling that no matter what he tried, he would always be a failure, a nobody. This attached itself to the only meaningful landmark in his life: his Jewish identity, expanding to the position of all the Jews in America. By the day after the assassination, distraught and sleep deprived, Ruby had lost all ability to know what was going on in his mind. That the President had been shot, in his home town no less, was bad enough, but it was also a blow to the aspirations of Jews in America with whom he so intensely identified. Having latched onto the right-wing plot, Ruby could only see conspiracy all around him, conspiracy which included the presidential assassin, Lee Harvey Oswald. In this manner Jack Ruby did achieve what he had wanted all his life: fame, but obtained in reverse. A man who but for a single act of impetuous violence, would have remained completely obscure, eminently forgettable, ended up as a footnote on the page.

\section{Acknowledgments}

Some information on the Ruby history is derived from an earlier chapter in my book: Robert M Kaplan (2011) The Exceptional Brain and How It Changed the World. Allen \& Unwin, Sydney, pp. 271-291.

Thanks to Hollace Ava, Tobias Brinkman, Edward Bristow, Adam Mendelsohn and Charles van Onselen for helpful suggestions.

This article is dedicated to my favourite Texas rabbi, Jack Segal and his wife Toby.

\section{Conflicts of interest}

The author declares that there are no conflicts of interest.

\section{References}

1. Texas Monthly. 2003.

2. Michel Englebert. Jack Ruby Believed. The Missouri Review. 1987;10(1):68-72.

3. Emma Harrison. Analyst studies Oswald and Ruby: Sees vengefulness pattern linked to childhood. The New York Times, USA. 1963;62 p.

4. Bugliosi Vincent. Reclaiming History: The Assassination of John F. Kennedy. WW Norton, Canada, USA. 2007;1696 p.

5. Warren Commission Report. Ruby's Childhood. 2013.

6. Jack Ruby with William Read Woodfield. Ruby Rose to Success From Life of Poverty. Sold Fireworks Fell Deeply in Love Partners with Brother. The Washington Post, USA. 1964;A7 p.

7. Austin C Wehrwein. Chicagoans Recall Jack Ruby As Ticket Scalper and Chiseler. The New York Times, USA. 1963;12 p.

8. Jack Ruby with William Read Woodfield. ibid.

9. Irving Howe. World of our fathers; the journey of the East European Jews to America and the life they found and made. Harcourt Brace Jovanovich, New York, USA. 1976;10(3):183-190. 
10. Irving Howe. ibid, 256-287 p

11. Riess Steven A. A Fighting Chance: The Jewish-American Boxing Experience, 1890-1940. American Jewish History. 1985;74(3):223.

12. Austin C Wehrwein. Ruby's Chicago Acquaintances Depict Him as the Victim of Stunted Adolescence: Were in Foster Home. The New York Times, USA. 1963;83 p.

13. Riess Steven A. ibid.

14. Charles Roberts. Ruby's Historic Bullet Fell Short of Big-Shot Ambition: Too Many Children. The Washington Post. Times Herald, USA. 1967;A20 p.

15. Warren Commission Report. Occupations and Activities. 1933.

16. Wehrwein AC. Chicagoans recall Jack Ruby as ticket scalper and chiseler. The New York Times, USA. 1963;12 p.

17. Robert HJ. Ruby, Who Wanted Esteem, Won a Place in History. New York Times, USA. 1963;2.

18. Berman LC. American Jews and the Ambivalence of Middle-Classness. American Jewish History. 2007;93(4):409-434.

19. Shapiro Edward S. Our Gang: Jewish Crime and the New York Jewish Community, 1900-1940. Journal of American Ethnic History. 1986;5(2):102-104.

20. Ruby, Who Wanted Esteem, Won a Place in History. New York Times (1923-Current file), USA. 1967;20.

21. The added middle name was in memory of his friend, union organiser Leon Cooke the financial secretary of Local 20467 of the Scrap Iron and Junk Handlers Union in Chicago who was killed in a dispute.

22. Time Magazine. The Assassination: A Nonentity for History. 1967.

23. Ronnie Dugger. 'Tell Me, Am I Insane?'-Ruby: Visiting Rabbi Says He Recalls Only Crowd, 'Leering' Oswald. The Washington Post, USA. 1963;A8 p.

24. Ronnie Dugger. ibid.

25. Jack Langguths. Jack Ruby-Profile of Oswald's Assassin: He Became a Promoter While Still in His Teens. The New York Times, USA. 1964;E10 p.
26. National Archives. Report of the President's Commission on the Assassination of President Kennedy. 1964.

27. Time Magazine. 1964;83(12):33.

28. Chicago Tribune. Author of Ad Aimed At Kennedy. 1963;5 p.

29. Obituary: Ruby, Who Wanted Esteem, Won a Place in History. New York Times. 1967;20 p.

30. Time Magazine. 1964;83(8):25

31. Garry Wills, Ovid Demaris. Jack Ruby: The Man Who Killed the Man Who Killed Kennedy. Ishi Press International. New York, USA. $2011 ; 119$.

32. Mayer M. The Trial of Jack Ruby, by John Kaplan and Jon R. Waltz. $1966 ; 83-87$.

33. Time Magazine. 1964;83(19):48.

34. Time Magazine. 1967;89(2):18.

35. Time Magazine. 1964;84(9):48.

36. Waldron Martin. Ruby Seriously Ill in Dallas Hospital. New York Times USA. $1966 ; 1 \mathrm{p}$

37. Waldron M. Ruby's cancer is widespread; Drugs called his only chance. The New York Times. USA. 1966;A12 p.

38. Ruby Buried in Chicago Cemetery alongside Graves of His Parents New York Times. USA. 1967;15 p.

39. New York Times. Ruby Testifies Pills Stimulated Shooting. Chicago Tribune, USA. 1965;1 p.

40. Bugliosi V. Reclaiming History: The Assassination of President John F. Kennedy. Lee Harvey Oswald and the Assassination of JFK. Popular media, New York, USA. 2007;17 p.

41. Dianne Holloway. Dallas and the Jack Ruby Trial: Memoir of Judge Joe B. Brown, Sr. Authors Choice Press. USA. 2001. 